\title{
Nutritional depletion in patients on long-term oxygen therapy and/or home mechanical ventilation
}

\author{
N.J.M. Cano*, H. Roth\#, I. Court-Fortuné ${ }^{\Uparrow}$ L. Cynober ${ }^{+}$, M. Gérard-Boncompain ${ }^{\S}$, A. Cuvelier ${ }^{f}$, \\ J-P. Laaban**, J-C. Melchior ${ }^{\# \#, ~ C . ~ P i c h a r d ~}{ }^{\text {\%巾 }}$, J-C. Raphaël ${ }^{++}$, C.M. Pison ${ }^{\#}$ and the Clinical Research \\ Group of the Société Francophone de Nutrition Entérale et Parentérale
}

Nutritional depletion in patients on long-term oxygen therapy andlor home mechanical ventilation. N.J.M. Cano, H. Roth, I. Court-Fortuné, L. Cynober, M.GérardBoncompain, A. Cuvelier, J-P. Laaban, J-C. Melchior, C. Pichard, J-C. Raphaël, C.M. Pison and the Clinical Research Group of the Société Francophone de Nutrition Entérale et Parentérale. (C) ERS Journals Ltd 2002.

ABSTRACT: The purpose of this study was to estimate the prevalence of malnutrition in outpatients on long-term oxygen therapy or home mechanical ventilation, to determine the relationships between malnutrition and impairment/disability and smoking and also to identify relevant tools for routine nutritional assessment.

In 744 patients (M:F 1.68, aged $65 \pm 15$ yrs) with chronic obstructive pulmonary disease $(C O P D, 40 \%)$, restrictive disorders $(27 \%)$, mixed respiratory failure $(15 \%)$, neuromuscular diseases $(13 \%)$ and bronchiectasis $(5 \%)$, body mass index (BMI), fatfree mass (FFM), serum albumin, transthyretin, 6-min walking test, forced vital capacity (FVC), forced expiratory volume in one second (FEV1) and blood gases were recorded.

FFM was the most sensitive parameter for detecting malnutrition, being abnormal in $53.6 \%$ of patients, while BMI was $<20$ in $23.2 \%$, serum albumin $<35 \mathrm{~g} \cdot \mathbf{L}^{-1}$ in $20.7 \%$, and serum transthyretin $<200 \mathrm{mg} \cdot \mathrm{L}^{-1}$ in $20 \%$. FFM depletion predominated in neuromuscular, bronchiectasis and restrictive disorders. BMI and FFM were correlated with FEV1, FVC and 6-min walking test. In multivariate analysis a $\mathbf{B M I}<\mathbf{2 0}$ was related to FEV1 and smoking habits, and a low FFM to smoking, FEV1 and female sex.

Malnutrition is highly prevalent in home-assisted respiratory patients and is related to causal disease, forced expiratory volume in one second, smoking and disability. Fatfree mass appeared to be the most sensitive and relevant nutritional parameter according to impairment and disability.

Eur Respir J 2002; 20: 30-37.

\begin{abstract}
*Service de Gastroentérologie et Nutrition, Clinique Résidence du Parc, Marseille, \#Dépt de Médecine Aiguë Spécialisée, Centre Hospitalier Universitaire (CHU), Grenoble, "Service de Pneumologie, CHU, Saint-Etienne, ${ }^{+}$Service de Biochimie $\mathrm{A}$ and ${ }^{* * \text { Service de }}$ Pneumologie et de Réanimation Respiratoire, Assistance Publique-Hôpitaux de Paris (AP-HP), Hôtel-Dieu, Paris, ${ }^{8}$ Service de Réanimation Médicale et d'Assistance Respiratoire, Hospices Civils de Lyon, Lyon, ${ }^{f}$ Service de Pneumologie, CHU, Rouen, and \#\#Service des Maladies Infectieuses, ${ }^{++}$Service de Réanimation Médicale, AP-HP, Hôpital Raymond Poincaré, Garches, France, Dépt de Nutrition Clinique, Hôpital Cantonal Universitaire, Genève, Suisse.
\end{abstract}

Correspondence: C.M. Pison, Dépt de Médecine Aiguë Spécialisée, Pneumologie, Hôpital A. Michallon, Centre Hospitalier Universitaire de Grenoble, BP217X 38043 Grenoble Cedex 9, France.

Fax: 33476765617

E-mail: CPison@chu-grenoble.fr

Keywords: Bioelectric impedance, fatfree mass, hypoxaemia, long-term oxygen therapy, malnutrition, smoking

Received: October 102001

Accepted after revision: January 17 2002

The present study was supported by the Sociéte Francophone de Nutrition Entérale et Parentérale and AstraZeneca, France.
The association between nutritional depletion and chronic respiratory diseases has been recognised for many years and mainly documented in chronic obstructive pulmonary disease (COPD) [1-4]. In this setting, body weight loss and muscle wasting have an impact on physical performance and respiratory muscle function and are responsible for an increase in healthcare requirements independently of the degree of airflow obstruction [5]. In COPD patients with chronic respiratory failure, long-term oxygen therapy (LTOT) and/or home mechanical ventilation (HMV) improve survival. Nevertheless, in such patients, the prognosis remains poor with a median survival of 3 yrs in COPD patients receiving LTOT [6]. Nutritional status appears to be a major factor for survival in these patients independently of lung function $[4,6,7]$. Conversely, nutritional support has been shown to improve body weight, fat-free mass (FFM), respiratory muscle function $[8,9]$ and prognosis in COPD patients [10]. Until now, the assessment of nutritional status in chronic respiratory failure patients on LTOT and/or HMV was based mainly on the calculation of body mass index (BMI, weight/height ${ }^{2}$ ) [4, 6], and data are lacking for 
important parameters such as body composition and protein markers of malnutrition. In addition, the reliability of BMI as a nutritional marker can be questioned in chronic respiratory disease due to fluid retention or obesity [3]. Thus, a more complete evaluation of nutritional status and of its relationship with the causes, the severity of respiratory failure and related inflammatory status is of major interest, particularly for screening patients requiring nutritional interventions during rehabilitation.

The aims of the present study were to: estimate the prevalence of malnutrition using various nutritional parameters according to the cause of chronic respiratory failure; determine the relationships between nutritional status and respiratory impairment/ disability and smoking; identify clinically-relevant tools for routine nutritional assessment.

\section{Methods}

Twenty-two outpatient clinics participated in a cross-sectional survey of the nutritional status of patients on home LTOT and/or HMV within the Association Nationale pour Le Traitment à domicile de 1'Insuffisance Respiratoire chronique (ANTADIR) network. Patients were consecutively recruited during the yearly outpatient examination, as required for reimbursement of home treatment fees. Inclusion criteria were age $>18 \mathrm{yrs}$, LTOT and/or HMV for $>3$ months, oxygen tension in arterial blood $\left(\mathrm{Pa}, \mathrm{O}_{2}\right)$ in a room air environment $\leqslant 8 \mathrm{kPa}$ at initiation of home treatment (not requested for neuromuscular patients) and informed consent. Exclusion criteria were sleep apnoea syndrome, history of exacerbation during the last 3 months and any condition compromising the prognosis within 6 months. Five respiratory diseases groups were considered: COPD, bronchiectasis, neuromuscular diseases, restrictive disorders (including pulmonary fibrosis and chest wall diseases) and mixed respiratory failure. The study protocol was approved by the Ethical Committee of the Société Francophone de Nutrition Entérale et Parentérale.

The length and type of home treatment, underlying respiratory disease, blood gases in room air and with LTOT/HMV, forced expiratory volume in one second (FEV1), forced vital capacity (FVC) [11], and 6-min walking distance test [12] in room air were recorded. The body weight was noted at the time of enrolment and $1 \mathrm{yr}$ prior to this and expressed as per cent of ideal body weight in medium frame size (BW\%IBW) according to life insurance tables [13]. Fat mass and FFM were evaluated using bio-electric impedance in $35.2 \%$ of patients $(50 \mathrm{kHz}$ apparatus, STAR 50; Spengler ( $\mathbb{R}$, Paris, France) and calculated according to a specific formula [14]. FFM and fat mass were expressed as per cent of IBW (FFM\%IBW) [3]. Serum albumin, transthyretin (prealbumin) and C-reactive protein were determined using conventional methods. A quality control of participating laboratories resulted in exclusion of albumin and transthyretin data from two centres (variation coefficient $>10 \%$ ), and C-reactive protein data from one. For each parameter, malnutrition was defined as: body weight loss $>10 \%$ during the year before enrolment, BW $\%$ IBW $<90 \%$, BMI $<20 \mathrm{~kg} \cdot \mathrm{m}^{-2}$, FFM $\%$ IBW $<63 \%$ in females or $<67 \%$ in males, serum albumin $<35 \mathrm{~g} \cdot \mathrm{L}^{-1}$ or serum transthyretin $<200 \mathrm{mg} \cdot \mathrm{L}^{-1}$ [3]. Patients were classified as corticoid users if they had been given oral corticoids for $>3$ months during the previous year. The number of antibiotic courses was recorded during the same period.

Results are presented as mean \pm SD. Analysis of variance was used to compare continuous variables between the five respiratory disease groups, with post hoc analysis using Fisher's Predicted Least Significant Difference test. The Chi-squared test was used to compare modalities of respiratory assistance. Relationships between nutritional parameters as well as between nutritional and functional parameters were tested using the Pearson's-correlation matrix with the Fisher's Z test. Determinants of BMI $<20$ were determined in the whole population, as well as in the subgroup of patients with FFM determination, using univariate and multivariate logistic regression analysis. Similarly, determinants of FFM $\%$ IBW $<63 \%$ in females and $<67 \%$ in males were established.

\section{Results}

\section{Demographic data and pulmonary function}

COPD represented $40 \%$ of patients, restrictive disorders $27 \%$, mixed respiratory failure $15 \%$, neuromuscular $13 \%$ and bronchiectasis 5\%. Among restrictive disorders, chest wall diseases and kyphoscoliosis accounted for $87 \%$ and pulmonary fibrosis for $13 \%$. Active smokers and exsmokers represented respectively $5.9 \%$ and $46.5 \%$ in all patients, $10.3 \%$ and $72.3 \%$ in COPD, $5.1 \%$ and $33.3 \%$ in bronchiectasis, $1.0 \%$ and $19.8 \%$ in neuromuscular diseases, $1.0 \%$ and $25.8 \%$ in restrictive disorders, and $7.2 \%$ and $41.4 \%$ in mixed respiratory failure (Chi-squared $=207.5, \quad \mathrm{p}<0.0001$ ). Smoking habits differed between males and females, active and exsmokers representing respectively $6.9 \%$ and $64.8 \%$ in males versus $4.3 \%$ and $15.8 \%$ in females (Chi-squared $=188.9, \mathrm{p}<0.0001$ ). As expected, age, sex ratio, pulmonary function as well as duration and type of home treatment varied significantly according to the respiratory disease. Mean duration of LTOT and/ or HMV was $55 \pm 60$ months, neuromuscular diseases and restrictive disorders exhibiting the greatest length of home treatment. COPD was the commonest cause of respiratory failure in males $(52 \%)$ and restrictive disorders in females $(42 \%)$. Neuromuscular patients were younger and more frequently treated by invasive ventilation than others. Noninvasive ventilation was more commonly used in restrictive disorders and mixed respiratory failure than in COPD (tables 1 and 2).

The median $\mathrm{Pa}_{\mathrm{a}} \mathrm{O}_{2}$ in room air was $7.7 \mathrm{kPa}, 57 \%$ of patients with a $P \mathrm{a}, \mathrm{O}_{2}<8 \mathrm{kPa}$ had severe respiratory failure. The median carbon dioxide tension in arterial blood $\left(\mathrm{Pa}, \mathrm{CO}_{2}\right)$ was $6.04 \mathrm{kPa}, 68 \%$ of patients exhibiting a $\mathrm{Pa}_{2} \mathrm{CO}_{2} \geqslant 5.86 \mathrm{kPa}$ without between-group differences. Hypoxaemia was more pronounced in COPD patients. Neuromuscular patients presented 
Table 1.-Demographic data and home treatment according to lung diseases

\begin{tabular}{|c|c|c|c|c|c|c|c|c|c|}
\hline & \multicolumn{3}{|c|}{ Patients } & \multicolumn{6}{|c|}{ Home treatment } \\
\hline & $\mathrm{n}$ & Age & $\begin{array}{l}\text { Sex } \\
\text { ratio } \\
M: F\end{array}$ & $\begin{array}{l}\text { Months on } \\
\text { home } \\
\text { treatment }\end{array}$ & LTOT & $\begin{array}{l}\text { Non- } \\
\text { invasive } \\
\text { HMV }\end{array}$ & $\begin{array}{c}\text { Invasive } \\
\text { HMV }\end{array}$ & $\begin{array}{c}\text { LTOT and } \\
\text { noninvasive } \\
\text { HMV }\end{array}$ & $\begin{array}{c}\text { LTOT and } \\
\text { invasive } \\
\text { HMV }\end{array}$ \\
\hline All patients & 744 & $65 \pm 15$ & 1.68 & $55 \pm 60$ & 308 & 160 & 71 & 191 & 14 \\
\hline COPD & 300 & $70 \pm 10^{+, \S, \uparrow \uparrow}$ & 4.26 & $40 \pm 45^{\S, * *}$ & $224^{++}$ & 18 & $3^{\S \S}$ & $54^{++}$ & 1 \\
\hline Bronchiectasis & 39 & $63 \pm 14, \S, * *$, ศศ & 0.62 & $48 \pm 44^{\S, * *}$ & 14 & 2 & 1 & 22 & 0 \\
\hline $\begin{array}{l}\text { Neuromuscular } \\
\text { diseases }\end{array}$ & 96 & $43 \pm 17^{\oplus,+, * * \text {, }}$ & 2.10 & $73 \pm 75^{\oplus,+,+\infty}$ & 0 & $43^{++}$ & $39^{++}$ & 9 & 5 \\
\hline $\begin{array}{l}\text { Restrictive } \\
\text { disorders }\end{array}$ & 198 & $68 \pm 12^{\boldsymbol{\top},+, \S, \boldsymbol{\oplus}}$ & 0.69 & 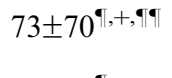 & 30 & 71 & $12^{++}$ & $78^{++}$ & 7 \\
\hline $\begin{array}{l}\text { Mixed } \\
\quad \text { respiratory } \\
\text { failure }\end{array}$ & 111 & $64 \pm 15^{\varpi, \S, * *}$ & 1.26 & $51 \pm 51^{\uparrow, * *}$ & 40 & 26 & 16 & $28^{++}$ & 1 \\
\hline p-value $\#$ & & $<0.0001$ & $<0.0001$ & $<0.0001$ & & & $<0.0$ & & \\
\hline
\end{tabular}

Data are presented as $\mathrm{n}$ or mean $+\mathrm{SD}$. LTOT: long-term oxygen therapy; HMV: home mechanical ventilation; COPD: chronic obstructive pulmonary disease. ${ }^{\#}$ : Analysis of variance (ANOVA) or Chi-squared p-value. ANOVA and post hoc test of Fisher; ${ }^{\top}$ : significantly different with COPD patients; ${ }^{+}$: with bronchiectasis patients; ${ }^{\S}:$ with neuromuscular disease patients; **: with restrictive disorder patients; and ${ }^{*}$ : with mixed respiratory failure. Chi-squared: significant variation in home treatment according to lung disease groups; ${ }^{++}$: corresponds to a significant increase in the prevalence of the type of home treatment; whereas. ${ }^{\S \S}$ : indicates a significant decrease.

the highest $P \mathrm{a}, \mathrm{O}_{2}$ and the lowest FVC. Hypoxaemia was corrected by LTOT and/or HMV whereas hypercapnia was only corrected by HMV. Twenty-two per cent were unable to complete the 6-min walking test and $20 \%$ required oxygen to perform this test. In nonneuromuscular patients, the 6-min walking distance was $238 \pm 107 \mathrm{~m}$ and did not vary according to the causal disease.

\section{Nutrition and inflammation assessment}

The nutrition and inflammation assessments are shown in (table 3 ). The median of body weight variation during the 12 months before the nutritional survey was equal to zero (data not shown). A loss in body weight $\geqslant 10 \%$ within $1 \mathrm{yr}$ was noted in $6.8 \%$ of patients. BW\%IBW differed significantly according to respiratory disease, with bronchiectasis and neuromuscular diseases being the most depleted. BMI was similar in males and females (data not shown) and varied significantly according to respiratory diseases. FFM $\%$ IBW varied according to the lung disease. Among non-neuromuscular patients, bronchiectasis subjects exhibited the lowest FFM. Serum albumin varied according to lung disease, with neuromuscular patients exhibiting the highest values. These differences persisted after adjustment for age. The median of serum C-reactive protein was $5 \mathrm{mg} \cdot \mathrm{L}^{-1}$ and C-reactive protein was $>10 \mathrm{mg} \cdot \mathrm{L}^{-1}$ in $27.8 \%$.

Figure 1 indicates the percentage of depleted patients in each group of respiratory disease depending on nutritional parameters. When all patients were considered, BW $\%$ IBW was $<90 \%$ in $30.8 \%$, BMI $<20$ in $23.2 \%$ and FFM $\%$ IBW was decreased in $53.6 \%$, with no differences between sex. Serum albumin was $<35 \mathrm{~g} \cdot \mathrm{L}^{-1}$ in $20.7 \%$, and serum transthyretin in $20 \%$. Transthyretin was weakly correlated with $\mathrm{BW} \% \mathrm{IBW}$, BMI and FFM\%IBW while serum albumin was not (table 4). Serum albumin and transthyretin were significantly interrelated in the whole studied population $(r=0.24, p<0.001)$ as in each group of respiratory disease, except for neuromuscular diseases. Serum $\mathrm{C}$-reactive protein was inversely correlated with serum albumin $(\mathrm{r}=-0.14, \mathrm{p}<0.001)$ and transthyretin $(\mathrm{r}=-0.12$, $\mathrm{p}<0.01)$ but did not show significant correlation with BW\%IBW, BMI, FFM $\%$ IBW and FM $\%$ IBW in all patients as well as in each respiratory disease group. In the year before enrolment, $14 \%$ of patients received oral corticoids for $>3$ months. These patients showed a significant decrease in BMI and albumin. After adjustment for FEV1 \% predicted, the effects of corticoids on albumin only, persisted $(p=0.04)$. The number of antibiotic courses was inversely but weakly correlated with BMI and serum albumin $(\mathrm{p}<0.05)$.

\section{Relationships between nutritional status and respiratory disability}

BMI and FFM $\%$ IBW were correlated with FEV1 and $\mathrm{FVC}, \%$ pred and the 6-min walking test. In contrast $\mathrm{BMI}$ and $\mathrm{FFM} \% \mathrm{IBW}$ were negatively related to $P$ a, $\mathrm{O}_{2}$ both in room air and with LTOT and/or HMV. Serum albumin appeared to be positively linked to $P \mathrm{a}, \mathrm{O}_{2}$ whereas serum transthyretin was negatively correlated with $\mathrm{Pa}, \mathrm{CO}_{2}$. Serum transthyretin, but not albumin, was correlated to pulmonary volumes. In non-neuromuscular patients, the comparison of patients with or without hypercapnia $\left(P \mathrm{a}, \mathrm{CO}_{2}>6 \mathrm{kPa}\right)$ did not show any difference in nutritional parameters except transthyretin, which was lower in hypercapnic subjects (table 5).

\section{Determinants of nutritional depletion}

Neuromuscular patients were excluded from this analysis since they were significantly younger and 

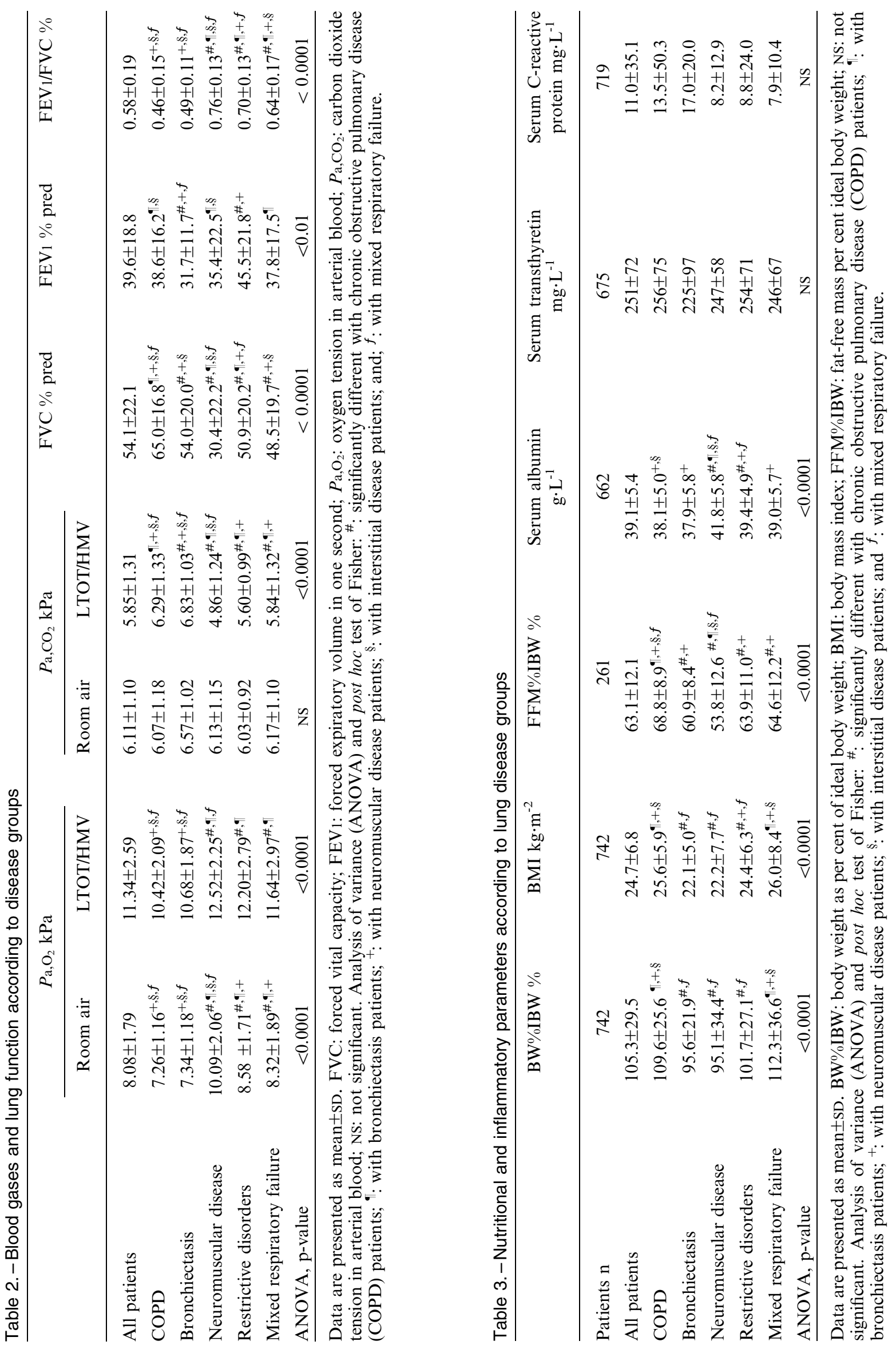


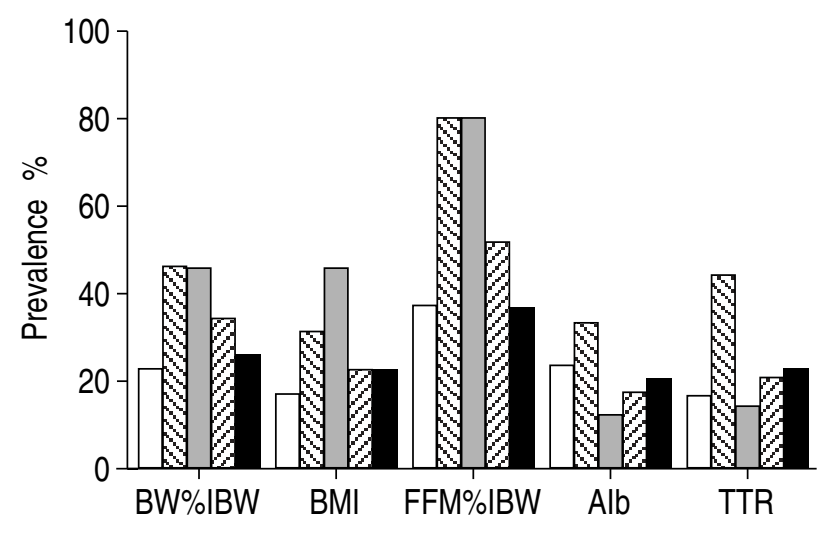

Fig. 1.-Percentage of malnourished patients as defined by per cent of ideal body weight (BW $\%$ IBW) $<90 \%$, body mass index (BMI) $<20$, fat-free mass expressed as a per cent of the ideal body weight $(\mathrm{FFM} \% \mathrm{IBW})<63 \%$ in females and $67 \%$ in males, serum albumin (Alb) $<35 \mathrm{~g} \cdot \mathrm{L}^{-1}$ or serum transthyretin (TTR) $<200 \mathrm{mg} \cdot \mathrm{L}^{-1}$, according to the disease. $\square$ : chronic obstructive pulmonary disease; $\mathbb{\mathbb { N }}$ : bronchiectasis; $\square$ : neuromuscular diseases; $\mathbb{Z}$ : restrictive disorders; $\mathbf{\square}$ : mixed respiratory failure.

characterised by a primary muscle defect. In univariate analysis, BMI $<20$ was related to $\mathrm{FEV} 1 \%$ pred (Chi-squared $=34.9, \mathrm{p}<0.0001$ ), $\mathrm{FVC} \%$ pred (Chi-squared $=29.2, \mathrm{p}<0.0001$ ), smoking habits (BMI lower in active smokers than in exsmokers and nonsmokers, Chi-squared $=20.0, \mathrm{p}<0.0001$ ), age (BMI increased with ageing, Chi-squared $=18.1, \mathrm{p}<0.0001$ ), $\mathrm{Pa}_{\mathrm{a}} \mathrm{O}_{2}$ in room air (negative correlation, Chisquared $=10.4, \mathrm{p}<0.01$ ), sex (females less depleted, Chi-squared=5.5, $\mathrm{p}<0.05)$ and $P \mathrm{a}, \mathrm{CO}_{2}$ in room air (negative correlation, Chi-squared $=5.1, \mathrm{p}<0.05$ ). In the multivariate analysis BMI was determined by FEV1 $\%$ pred (Chi-squared $=37.2, \quad \mathrm{p}<0.0001$ ) and smoking habits (Chi-squared $=19.8, \mathrm{p}<0.0001$ ). The same results were achieved in the subgroup of patients who underwent bio-impedance analysis.

In univariate analysis, FFM depletion, defined by FFM $\%$ IBW $<63 \%$ in females or $<67 \%$ in males, was related to smoking habits (FFM\%IBW lower in active smokers than in exsmokers and nonsmokers, Chi-squared $=19.1, \mathrm{p}<0.0001$ ), FEV1 \% pred (Chisquared $=8.3, \mathrm{p}<0.01$ ), sex (females more depleted, Chi-squared $=5.5, \quad \mathrm{p}<0.05)$ and age $(\mathrm{FFM} \% \mathrm{IBW}$ decreased with ageing, Chi-squared $=5.1, \mathrm{p}<0.05)$, whereas in multivariate analysis FFM depletion was determined by smoking habits (Chi-squared $=15.7$,

Table 4.-Relationships of serum albumin and transthyretin with body weight as per cent of ideal body weight (BW\%IBW), body mass index (BMI), and fat-free mass as a per cent of ideal body weight (FFM\%IBW)

\begin{tabular}{|c|c|c|c|c|c|}
\hline & \multirow{2}{*}{$\begin{array}{c}\text { Patients } \\
n\end{array}$} & \multicolumn{2}{|c|}{ Serum albumin } & \multicolumn{2}{|c|}{ Serum transthyretin } \\
\hline & & $\mathrm{r}$ & p-value & $\mathrm{r}$ & p-value \\
\hline BW\%IBW & 669 & NS & NS & 0.17 & $<0.0001$ \\
\hline BMI & 669 & NS & NS & 0.16 & $<0.0001$ \\
\hline FFM $\%$ IBW & 115 & NS & NS & 0.14 & $<0.05$ \\
\hline
\end{tabular}

NS: not significant.
Table 5. - Correlations of nutritional parameters with blood gases, pulmonary function tests and disability

\begin{tabular}{lcccc}
\hline & BMI & $\begin{array}{c}\text { FFM\%- } \\
\text { IBW }\end{array}$ & $\begin{array}{c}\text { Serum } \\
\text { albumin }\end{array}$ & $\begin{array}{c}\text { Serum } \\
\text { transthyretin }\end{array}$ \\
\hline $\mathrm{Pa}_{\mathrm{a}, \mathrm{O}_{2}}$ room air & -0.14 & -0.30 & 0.18 & $\mathrm{NS}$ \\
& $<0.001$ & $<0.001$ & $<0.0001$ & \\
$\mathrm{~Pa}_{\mathrm{a}, \mathrm{CO}_{2} \text { room air }}$ & $\mathrm{NS}$ & $\mathrm{NS}$ & $\mathrm{NS}$ & -0.18 \\
& & & & $<0.0001$ \\
FEV1 \% pred & 0.32 & 0.24 & $\mathrm{NS}$ & 0.10 \\
& $<0.0001$ & $<0.001$ & & $<0.05$ \\
FVC \% pred & 0.27 & 0.35 & $\mathrm{NS}$ & 0.10 \\
& $<0.0001$ & $<0.0001$ & & $<0.05$ \\
6-min walking & 0.12 & 0.27 & $\mathrm{NS}$ & $\mathrm{NS}$ \\
test & $<0.01$ & 0.0001 & & \\
\hline
\end{tabular}

BMI: body mass index; FFM\%IBW: fat-free mass per cent ideal body weight; FVC: forced vital capacity; FEV1: forced expiratory volume in one second; $P \mathrm{a}, \mathrm{O}_{2}$ : oxygen tension in arterial blood; $P_{\mathrm{a}}, \mathrm{CO}_{2}$ : carbon dioxide tension in arterial blood; NS: not significant. Correlation co-efficients and p-values between nutritional and functional parameters are given using Fisher's $\mathrm{Z}$ test.

$\mathrm{p}=00004)$, FEV1 \% pred (Chi-squared=12.1, $\mathrm{p}=0.0005)$ and sex (Chi-squared $=5.1, \mathrm{p}=0.02$ ).

\section{Discussion}

Nutritional status has been demonstrated to be a major factor for predicting survival in COPD independently of lung function [4-7]. The present study is original with respect to the characteristics of patients and the nutritional approach. First, this study specifically addressed stable outpatients with chronic hypoxaemia (apart from neuromuscular diseases), requiring LTOT or/and HMV. According to these criteria, the present study addressed not only COPD patients but patients with respiratory failure of various aetiologies including neuromuscular patients even if they were younger and suffered from intrinsic neuromuscular disease. Secondly, this study provided the first multiparameter nutritional approach of malnutrition in such hypoxaemic patients. Finally, these data made it possible to assess the relationship between nutrition and disability. This study was further characterised, by the number of patients and their stability attested by the length of home respiratory care and the absence of recent hospitalisation, body weight change or inflammatory syndrome. Among the major findings was the high prevalence of malnutrition, as defined by a BMI $<20 \mathrm{~kg} \cdot \mathrm{m}^{-2}$ and its variations with underlying lung disease. This study further showed the high sensitivity of FFM $\%$ IBW, which revealed a lean body mass depletion in $53.6 \%$ of patients, while BMI was altered in only $23.2 \%$. FFM\%IBW also exhibited better correlations with ventilatory pump and physical performance. Finally, nutritional depletion appeared to be related to respiratory function and smoking habits. Study limitations included the lack of data on nutritional intake and the fact that body composition was evaluated in only one-third of patients. However, the comparison of 
patients, in whom bio-electric impedance was performed, with others did not show any difference in the cause and the severity of respiratory failure (data not shown), suggesting that the body composition data were representative of the whole population.

The comparison of the present study with the ANTADIR study [6] showed that the two series were very similar and suggested that the present data are representative of French patients on LTOT and/or HMV. In fact, in each group of lung disease, age and sex distribution as well as $\mathrm{Pa}, \mathrm{O}_{2}$ in room air, $\mathrm{FVC}$ and FEV1 \% pred were similar. However, due to a higher recruitment of neuromuscular patients, a greater proportion of neuromuscular disease was observed (12.9 versus $4.2 \%$ ). Another difference was the higher proportion of patients with $\mathrm{HMV}$, which probably reflected recent changes (since the beginning of the 1980s) in home management of respiratory failure.

Nutritional data varied according to lung disease (table 3, fig. 1). Most studies [2, 3, 7, 5-18] have examined stable, non-LTOT and/or HMV COPD outpatients. Very few studies $[6,19]$ have been specifically devoted to the nutritional status of COPD patients on LTOT and/or HMV. In the present series, the percentage of COPD patients with BMI $<20 \mathrm{~kg} \cdot \mathrm{m}^{-2}(17.3 \%)$ appeared to be lower than in the Maastricht series [3, 19]. When compared to the most severe COPD patients from the Maastricht group, COPD patients from the present series showed a lower prevalence of malnutrition. In the present COPD series, BW\%IBW was $<90 \%$ in 23.3 versus $46 \%$ in the Maastricht study [3], FFM $\%$ IBW $<63 \%$ in females and $67 \%$ in males in 37.5 versus $48 \%$, serum albumin $<35 \mathrm{~g} \cdot \mathrm{L}^{-1}$ in 23.8 versus $44 \%$, and serum transthyretin $<200 \mathrm{mg} \cdot \mathrm{L}^{-1}$ in 17.1 versus $23 \%$. Data evaluating the role of smoking habits and subtypes of COPD (emphysema versus chronic bronchitis), which may explain the differences between the two series, are lacking. The difference between the results achieved in the two studies may be related to the much higher use of corticoids in the Maastricht series ( 73.9 versus $14 \%$ in the present study) [19]. The same group recently reported a negative relationship between maintenance treatment with oral corticoids and BMI [19].

Non-COPD patients with LTOT and/or HMV form an inhomogeneous group in which nutritional status has been poorly studied. When compared with data from the ANTADIR study [15], the patients in the present study presented with a similar BMI in the different groups of causal disease, with bronchiectasis and neuromuscular diseases showing the lowest values (table 3 , fig. 1). Patients with bronchiectasis as compared with COPD, showed significantly lower values of BW\%IBW, BMI and FFM $\%$ IBW. Considering the different groups of lung diseases, patients with bronchiectasis also exhibited the lowest values of serum albumin and transthyretin and the highest values of serum C-reactive protein. Although between-group differences were not always significant, these data suggest a higher inflammatory activity in patients with bronchiectasis [20]. As described previously in younger patients with Duchenne disease [21-22], neuromuscular patients are characterised by the magnitude of FFM depletion. However, most of these patients showed normal serum albumin, transthyretin and C-reactive protein suggesting that in these patients muscle wasting was mostly determined by muscle disease and not by malnutrition or inflammation. As compared to COPD, restrictive disorders and mixed respiratory failure were characterised by a higher proportion of patients with reduced $\mathrm{FFM} \% \mathrm{IBW}$

Figure 1 and table 3 showed that FFM was the most sensitive tool for detecting malnutrition: FFM was altered in $37-80 \%$ of patients according to respiratory disease groups, while BMI was $<20$ in only $17-39 \%$. Although it was recognised that overall correlation between nutritional parameters and respiratory impairment/disability was weak (table 5), FFM appeared to be better correlated than BMI with functional parameters such as FEV1, FVC and 6-min walking test. The interest of FFM evaluation would have probably been strengthened if this parameter had been available in a higher number of patients. Malnutrition per se was previously reported to impair diaphragm function, as assessed by lung volumes, in severely malnourished patients with anorexia nervosa [23]. The apparently paradoxical inverse relationship between $\mathrm{Pa}_{\mathrm{a}} \mathrm{O}_{2}$ in room air and BMI and FFM may be explained by a higher oxygen consumption due to a bigger body cell mass. Another explanation may be related to the variations of $\mathrm{Pa}_{\mathrm{a}} \mathrm{O}_{2}$ according to the subtype of COPD patients. When compared to chronic bronchitis patients, emphysematous patients are characterised by a more pronounced depletion and a higher $\mathrm{Pa}_{2} \mathrm{O}_{2}$ in room air [24]. Interestingly, transthyretin appeared to be correlated in a coherent manner with BMI, FFM, lung volumes and $\mathrm{Pa}_{\mathrm{a}} \mathrm{CO}_{2}$. Both albumin and transthyretin were negatively correlated with $\mathrm{C}$-reactive protein showing that during respiratory failure, as in other diseases, albumin and transthyretin serum levels are dependent on both nutritional status and inflammation [25]. The prognostic values of these plasma proteins remain to be evaluated.

Although a relationship between malnutrition and inflammation, as assessed by plasma tumour necrosis factor (or the soluble 55 fraction of the receptor to TNF, was reported in stable COPD patients [20, 26, 27], in the present series BMI and FFM\%IBW were not related to serum $\mathrm{C}$-reactive protein. Multivariate analysis showed that BMI was independently determined by FEV1 and smoking habits and that FFM\%IBW was related to FEV1, smoking habits and sex. These data are consistent with the effects of smoking on food intake [28] and energy expenditure [29] and underline the deleterious effects of active smoking on nutritional status in patients with chronic respiratory failure. Similarly, airflow obstruction has been proposed as a factor of hypermetabolism in COPD patients, particularly during exacerbations [30].

To conclude, the present study is the first specifically devoted to the nutritional assessment of a population of stable outpatients, defined by hypoxaemia or hypercapnia, requiring long-term oxygen therapy or/and home mechanical ventilation. Fat-free mass and fat mass, expressed as a per cent of the ideal 
body weight, was more sensitive than the body mass index for detecting malnutrition and showed better correlation with ventilatory pump and disability. Airflow obstruction and smoking habits appeared to be independent determinants of malnutrition. A cohort study is required in order to analyse the predictive value of these nutritional parameters on patient morbidity and mortality.

Acknowledgements. The authors would like to thank the physicians responsible for patient recruitment: J.F. Muir, B. Tengang (Service de Pneumologie, CHU, Rouen, France); P. Rodriguez, F. Louis (Centre Henri Bazire, Saint Julien de Ratz, France); G. Jang (Service de Médecine $\mathrm{CH}$, Briançon, France); E. Chailleux, J.R. Ordonneau (Service de Pneumologie, CHU, Nantes, France); E. Beaumlin (Centre Médical de Gravenand, Genilac); J.M. Polu (Service de Pneumologie, CHU, Nancy, France); P. Beuret, A. Canamela (Service de Réanimation, CH Roanne, France); C. Perrin (Service de Pneumologie, CHU, Nice, France); J. Labrousse, J.L. Diehl (Service de Réanimation Médicale, AP-HP, Boucicaut, Paris, France); J.M. Sainty, V. Quenee (Service de Réanimation Médicale, CHU, Marseille, France); B. Herrer (Centre Médical des Forcilles, Ferolles Attily, France); D. Caillaud, L.T.N. Guyen (Service de Pneumologie, CHU, Clermont-Ferrand, France); D. Dusser, J. Lacronique (Service de Pneumologie, AP-HP Hôpital Cochin, Paris, France); V. Gauthier (APARD, Montpellier, France); T. Chinet (Service de Pneumologie, AP-HP, Boulogne, France); A. Mallart, T. Perez (Service de Pneumologie, CHU, Lille, France); J.M. Tschopp (Service de Pneumologie, Montana, Suisse); Association Nationale pour le Traitement A Domicile de l'Insuffisance Respiratoire chronique (ANTADIR). The authors would also like to thank J. Quentin, S. Hamant for technical assistance, and D. Cardenas for taking care of the quality control of serum protein measurements.

\section{References}

1. Fiaccadori E, Del Canale S, Coffrini E, et al. Hypercapnic-hypoxemic chronic obstructive pulmonary disease (COPD): influence of severity of COPD on nutritional status. Am J Clin Nutr 1988; 48: 680 685.

2. Wilson DO, Rogers RM, Wright EC, Anthonisen NR. Body weight in chronic obstructive pulmonary disease. The National Institutes of Health intermittent positive-pressure breathing trial. Am Rev Respir Dis 1989; 139: 1435-1438.

3. Schols AMWJ, Soeters PB, Dingemans AMC, Mostert R, Frantzen PJ, Wouters EFM. Prevalence and characteristics of nutritional depletion in patients with stable COPD eligible for pulmonary rehabilitation. Am Rev Respir Dis 1993; 147: 1151-1156.

4. Landbo C, Prescott E, Lange P, Vestbo J, Almdal TP. Prognostic value of nutritional status in chronic obstructive pulmonary disease. Am J Respir Crit Care Med 1999; 160: 1856-1861.
5. Decramer M, Gosselink R, Troosters T, Verschueren M, Evers G. Muscle weakness is related to utilization of health care resources in COPD patients. Eur Respir $J$ 1997; 10: 417-423.

6. Chailleux E, Fauroux B, Binet F, Dautzenberg B, Polu $\mathrm{J}-\mathrm{M}$. Predictors of survival in patients receiving domiciliary oxygen therapy or mechanical ventilation. Chest 1996; 109: 741-749.

7. Gray-Donald K, Gibbons L, Shapiro SH, Macklem PT, Martin JG. Nutritional status and mortality in chronic obstructive pulmonary disease. Am J Respir Crit Care Med 1996; 153: 961-966.

8. Rogers RM, Donahoe M, Constantino J. Physiologic effects of oral supplemental feeding in malnourished patients with chronic obstructive pulmonary disease. Am Rev Respir Dis 1992; 146: 1511-1517.

9. Schols AMWJ, Soeters PB, Mostert R, Pluymers RJ, Wouters EFM. Physiologic effects of nutritional support and anabolic steroids in patients with chronic obstructive pulmonary disease. Am J Respir Crit Care Med 1995; 152: 1268-1274.

10. Schols AMWJ, Slangen J, Volovics L, Wouters EFM. Weight loss is a reversible factor in the prognosis of chronic obstructive pulmonary disease. Am J Respir Crit Care Med 1998; 157: 1791-1797.

11. Quanjer PH. Standardised lung function testing. Bull Eur Physiopathol Respir 1983; 19: 7-44.

12. Guyatt GH, Pugsley SO, Sullivan MJ, et al. Effect of encouragement on walking test performance. Thorax 1984; 39: 812-822.

13. Company Metropolitan Life Insurance. New weight standards for men and women. Stat Bull Metrop Life Found 1983; 64: 1-4.

14. Kyle UG, Pichard C, Rochat T, Slosman DO, Fitting J-W, Thiebaud D. New bioelectrical impedance formula for patients with respiratory insufficiency: comparison to dual-energy X-ray absorptiometry. Eur Respir J 1998; 12: 960-966.

15. Openbrier DR, Irwin MM, Rogers RM, et al. Nutritional status and lung function in patients with emphysema and chronic bronchitis. Chest 1983; 83: 17-22.

16. Braun SR, Dixon RM, Keim NL, Luby M, Anderegg A, Shrago ES. Predictive clinical value of nutritional assessment factors in COPD. Chest 1984; 85: 353-357.

17. Gray-Donald K, Gibbons L, Shapiro SH, Martin JG. Effects of nutritional status on exercise performance in patients with chronic obstructive disease. Am Rev Resp Dis 1989; 140: 1544-1548.

18. Schols AMWJ, Mostert R, Soeters PB, Greve H, Wouters EFM. Inventory of nutritional status in patients with COPD. Chest 1989; 96: 247-249.

19. Schols AMWJ, Wesseling G, Kester ADM, et al. Dose dependent increased mortality risk in COPD patients treated with oral glucocorticoids. Eur Respir J 2001; 17: 337-342.

20. Schols AMWJ, Buurman WA, Staal-van den Brekel AJ, Dentener MA, Wouters EFM. Evidence for a relation between metabolic derangements and increased levels of inflammatory mediators in a subgroup of patients with chronic obstructive pulmonary disease. Thorax 1996; 51: 818-824.

21. Willig TN, Carlier L, Legrand M, Rivière H, Navarro J. Nutritional assessment in Duchenne muscular dystrophy. Dev Med Child Neurol 1993; 35: 1074-1082.

22. Hankard R, Gottrand F, Turck D, Carpentier A, Romon M, Farriaux JP. Resting energy expenditure 
and energy substrate utilization in children with Duchenne muscular dystrophy. Pediatr Res 1996; 40: 29-33.

23. Murciano D, Rigaud D, Pingleton S, Armangaud MH, Melchior JC, Aubier M. Diaphragmatic function in severely malnourished patients with anorexia nervosa. Effects of renutrition. Am J Respir Crit Care Med 1994; 150: 1569-1574.

24. Engelen MP, Schols AM, Lamers RJ, Wouters EF. Different patterns of chronic tissue wasting among emphysema and chronic bronchitis patients. Clin Nutr 1999; 18: 275-280.

25. Ingenbleek Y, Van Den Schrieck HG, De Nayer P, De Visscher M. Albumin, transferrin and thyroxinbinding prealbumin/retinol retinol binding protein (TBPA/RBP) complex in the assessment of malnutrition. Clin Chim Acta 1975; 63: 61-67.

26. Nguyen LT, Bedu M, Caillaud D, et al. Increased resting energy expenditure is related to plasma
TNF-alpha concentration in stable COPD patients. Clin Nutr 1999; 18: 269-274.

27. Schols AMWJ, Creutzberg EC, Buurman WA, Campfield LA, Saris WH, Wouters EFM. Plasma leptin is related to pro-inflammatory status and dietary intake in patients with COPD. Am J Respir Crit Care Med 1999; 160: 1220-1226.

28. Nicklas BJ, Tomoyasu N, Muir J, Goldberg AP. Effects of cigarette smoking and its cessation on body weight and plasma leptin levels. Metabolism 1999; 48: 804-808.

29. Warwick PM, Busby R. Prediction of twenty-fourhour energy expenditure in a respiration chamber in smokers and non-smokers. Eur J Clin Nutr 1993; 47: 600-603.

30. Jouniaux V, Mayeux I. Oxygen cost of breathing in patients with emphysema or chronic bronchitis in acute respiratory failure. Am J Respir Crit Care Med 1995; 152: 2181-2184. 